\title{
Ultrastructural aspects of hepatic coccidiosis caused by Goussia lusca n. sp. (Apicomplexa: Coccidia) infecting Trisopterus luscus (Gadidae) from the NE Atlantic Ocean
}

\author{
C. Gestal, C. Azevedo* \\ Department of Cell Biology, Institute of Biomedical Sciences (ICBAS, UP), and Laboratory of Protoparasitology, \\ Center for Marine and Environmental Research (CIIMAR, UP), University of Porto, Largo Prof. Abel Salazar, \\ no. 2, Porto 4099-003, Portugal
}

\begin{abstract}
Goussia lusca n. sp. is described from the liver of pouting Trisopterus luscus from the NE Atlantic Ocean in Ibero-Atlantic Portuguese and Spanish waters. Mature oocysts were 31.7 (28.8 to 35.4) $\mu \mathrm{m}$ in diameter. Each oocyst contained 4 ellipsoidal sporocysts arranged in an aleatory position, and measuring $\sim 13.7 \times 9.2 \mu \mathrm{m}$. Each sporocyst contained 2 sporozoites. Ultrastructurally, the sporocyst wall consisted of a dense inner layer $115 \mathrm{~nm}$ thick, transversely striated, regularly intercalated by thin grooves with electron-lucent spaces, and separated from the outer layer by a thin, light (electron-lucent) space. The outer layer was multilamellated and consisted of parallel dense bands alternating with light spaces. These lamellae formed filamentous extensions of the wall. The dehiscence suture, a characteristic feature of the genus, was present in the sporocysts. No external clinical signs were observed in the host fish. Parasites observed in the liver tissue were often enveloped in a yellowish-brown matrix, generally known as 'yellow bodies'. Sometimes sporocysts were observed in direct contact with the liver cells. Parasites in degeneration and aggregations of amylopectin granules were frequently observed surrounded by host inflammatory cells. In severe infections, we observed large agglomerations of oocysts encapsulated by layers of concentrically arranged connective tissue forming large granulomas, which caused significant replacement of the host liver parenchyma by the parasite.
\end{abstract}

KEY WORDS: Coccidia · Goussia lusca $\cdot$ Trisopterus luscus $\cdot$ Liver $\cdot$ Ultrastructure $\cdot$ Ibero-Atlantic waters

\section{INTRODUCTION}

Species of the genus Goussia are coccidian parasites that have been found to cause significant damage in the digestive tract of teleost fish (Dyková \& Lom 1981, Costa \& Mackenzie 1994, Azevedo 2001, Gestal \& Azevedo 2005). They are pathogens of considerable importance in both wild fisheries and fish farms (Anderson \& Gordon 1982, Kent \& Hedrick 1985). Severe infections affect fish condition and may cause mortalities. Intestinal Goussia species seem to be more numerous, and such infections have to date been studied in greater detail than those inhabiting extra-intestinal sites. Thus, the taxonomic description and pathol- ogy produced by extra-intestinal fish coccidia is incomplete, and the information available on this group of parasites in North Atlantic fish is particularly scarce (Costa \& Mackenzie 1994, Gestal \& Azevedo 2005).

Extra-intestinal coccidians infecting more than one host species of fish are common. Goussia clupearum has been found parasitizing the liver of at least 2 clupeid species (Sardina pilchardus, Clupea harengus), 2 scombroid species (Scomber scombrus and S. japonicus), 3 gadid species (Micromesistius poutassou, Trisopterus esmarkii and T. minutus), 1 carangid species (Trachurus trachurus) and 1 species of belonid (Belone belone). A further 5 Goussia species have also been described parasitizing marine fish at 
extra-intestinal locations, namely Goussia cruciata in the liver of T. trachurus, Goussia gadi in the swimbladder of 2 gadid species (Gadus morhua and Melanogrammus aeglefinus), Goussia caseosa in the swimbladder of the gadid Macrourus berglax, and Goussia spraguei and Goussia auxidis in the kidney of G. morhua, M. aeglefinus, Thunnus albacares and Scomber australasicus.

Until recently, there was increasing evidence that piscine coccidians do not have the narrow host specificity characteristic of mammalian and avian coccidians (Dyková \& Lom 1983). However, Molnar et al (2005) have proved that Goussia spp. of fish have relatively strict host specificity. Host-parasite interactions, environmental conditions and geographical separation may combine to influence host specificity and host response (Fournie \& Overstreet 1993).

The present paper describes some light microscopy and ultrastructural aspects of morphology and pathol- ogy induced by a new extra-intestinal Goussia species, Goussia luscus n. sp., the agent that causes hepatic coccidiosis in one of the most commercially exploited fish populations in temperate waters of NE Atlantic, the pouting Trisopterus luscus.

\section{MATERIALS AND METHODS}

Specimens of the pouting Trisopterus luscus Linnaeus, 1758 (Teleostei: Gadidae) were sampled from commercial vessels off Galicia (NW Spain) and the Portuguese North Atlantic coast. Small fragments of parasitized fresh liver were examined by light microscopy. Sporulated oocysts were observed and photographed using Nomarski differential interference-contrast (DIC) optics. Measurements were made either directly on living oocysts using a calibrated micrometer or from photographs obtained from living oocysts.
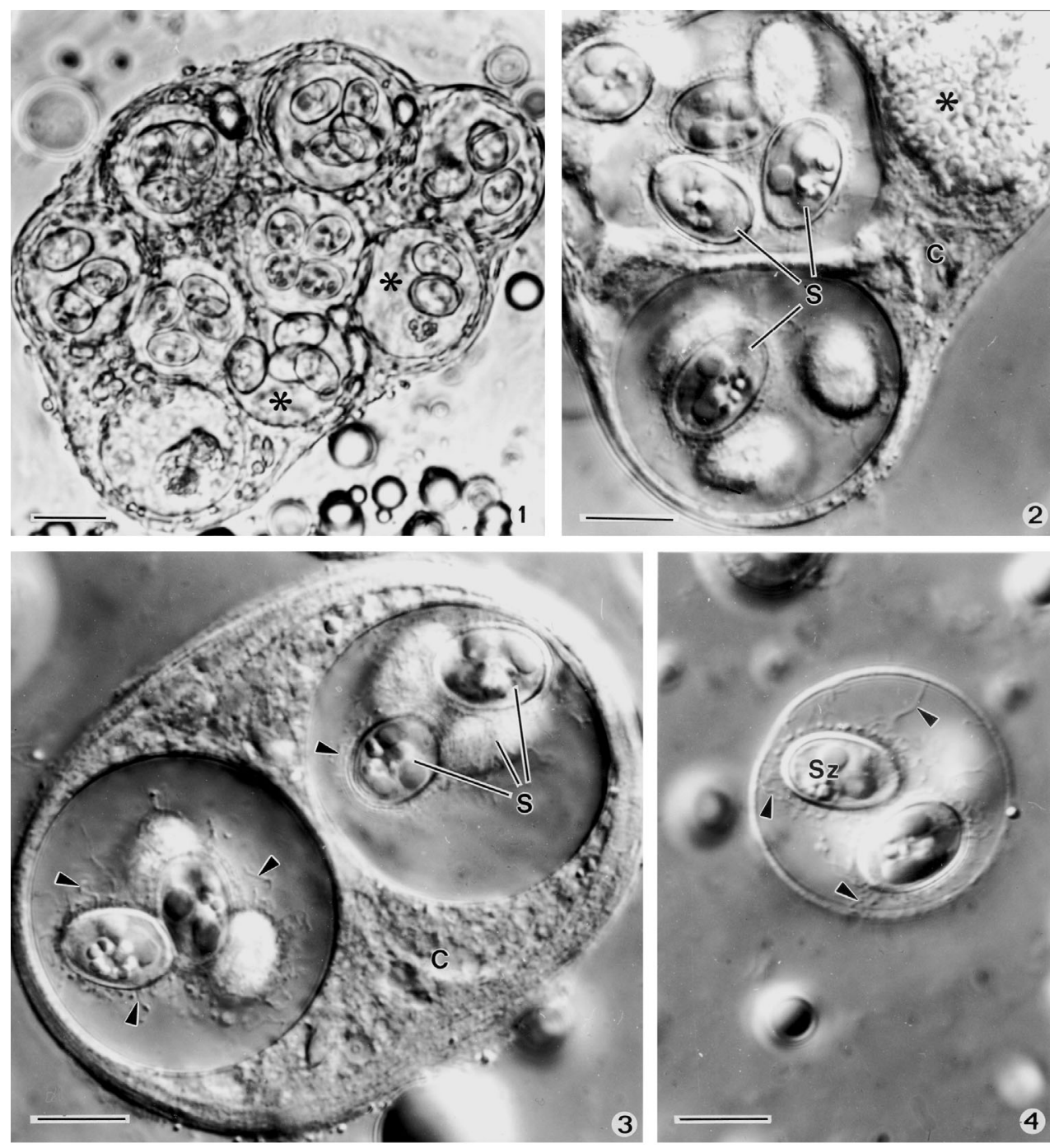

Figs. 1 to 4 . Goussia lusca n. sp. infecting Trisopterus luscus. Light micrographs (DIC) of sporogonial stages of $G$. lusca in the liver of T. luscus showing oocysts with 4 sporocysts. Fig. 1. Large agglomerations of sporulated oocysts (*) encapsulated by layers of concentrically arranged connective tissue forming large granulomas; scale bar $=20 \mu \mathrm{m}$. Figs. $2 \&$ 3. Aggregation of oocysts in the liver tissue enveloped in a thin fibrotic capsule, showing the rest of the necrotic host cell, yellowish-brown matrix or 'yellow body' (C), and remains of an aborted oocyst inside the 'yellow body' $(*)$. Each oocyst contains 4 sporocysts (S). The sporocyst wall shows the filamentous extensions (Fig. 3, arrowheads); scale bar = $10 \mu \mathrm{m}$. Fig. 4. Isolated oocyst showing the sporocysts inside, and large filamentous extensions in the sporocyst wall (arrowheads). Each oocyst contains 2 sporozoites $(\mathrm{Sz}) ;$ scale bar $=10 \mu \mathrm{m}$ 

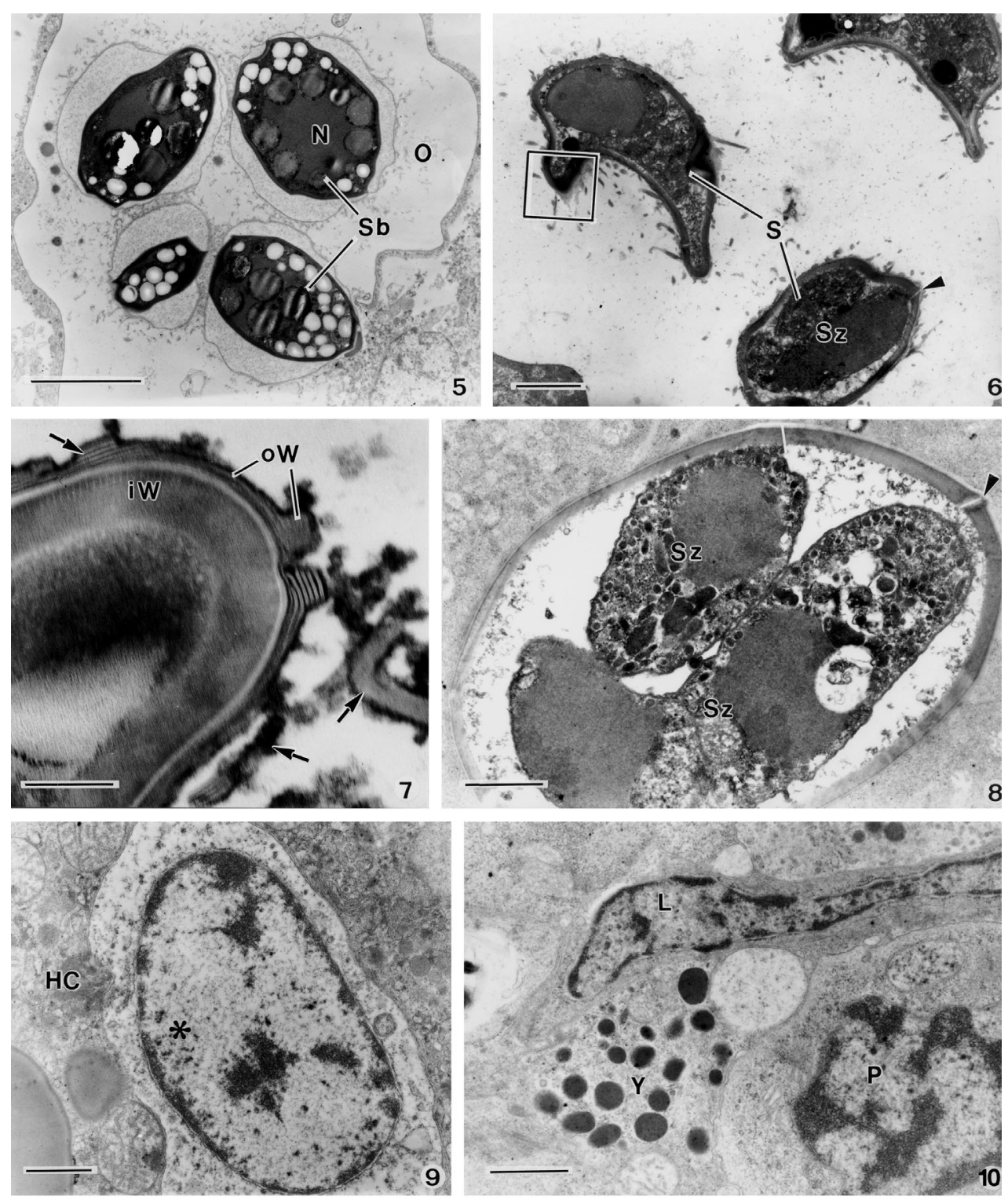
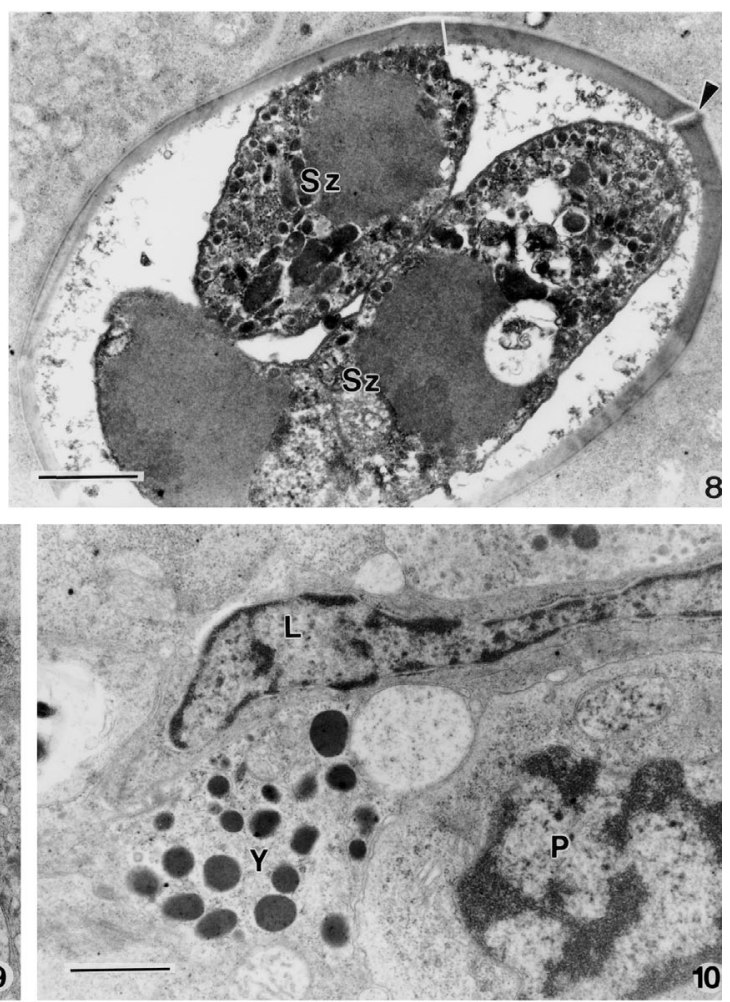

Figs. 5 to 10 . Goussia lusca n. sp. infecting Trisopterus luscus. Ultrathin section of different aspects of sporogonic stages of G. lusca infecting the liver of $T$. luscus. Fig. 5. Oocyst (O) containing 4 aleatory disposed sporoblasts $(\mathrm{Sb})$ in the developmental phase and showing a prominent nucleus $(\mathrm{N})$; scale bar $=5 \mu \mathrm{m}$. Fig. 6. Mature sporocysts (S) containing 2 sporozoites (Sz) showing the symmetrically opposite disposition of the dehiscence suture (arrowhead). The boxed area showing a completely formed sporocyst wall is enlarged in Fig. 7 ; scale bar $=2 \mu \mathrm{m}$. Fig. 7 . Detail of the sporocyst wall (Fig. 6), showing regular transverse striation of the inner wall (iW), and the multilamellated outer wall (oW) with external projections (arrows); scale bar $=0.2 \mu \mathrm{m}$. Fig. 8. Isolated sporocyst in direct contact with the liver tissue of $T$. rachurus showing the dehiscence suture of the sporocyst wall (arrowhead), and 2 sporozoites inside (Sz); scale bar $=1 \mu \mathrm{m}$. Fig. 9. Degenerate gamogonic stage $(*)$ in the host cell $(\mathrm{HC})$; scale bar $=1 \mu \mathrm{m}$. Fig. 10. Detail of the yellowish-brown matrix (Y) surrounding degenerated young stage of the parasite $(\mathrm{P})$ with a lymphocyte (L) adjacent; scale bar $=1 \mu \mathrm{m}$
Isolation and purification of the parasite. $\mathrm{Pa}$ rasitized liver tissue extracts containing Goussia oocysts were homogenized, and tissue homogenates were filtered through 2 layer nylon gauze sieves of 100, 60 and $40 \mu \mathrm{m}$ pore diameter (Millipore) to remove large pieces of host tissue. Purification of the parasite was performed following protocols based on Percoll gradients (Gestal et al. 1999). Samples of isolated and purified sporocysts were collected and fixed in glutaraldehyde for later scanning electron microscopy studies.

Transmission and scanning electron microscopy. For transmission electron microscopy (TEM) analysis, small fragments of the infected tissues was fixed in $2.5 \%$ glutaraldehyde in $0.2 \mathrm{M}$ sodium cacodylate buffer $(\mathrm{pH}$ 7.4) for $4 \mathrm{~h}$ at $4^{\circ} \mathrm{C}$, washed for $24 \mathrm{~h}$ at $4^{\circ} \mathrm{C}$ in the same buffer and post-fixed in buffered $2 \% \mathrm{OsO}_{4}$ for $2 \mathrm{~h}$ at the same temperature. After dehydration in a graded ethanol series and propylene oxide, the infected tissue was embedded in Epon. Semithin sections were stained with methylene blue. Ultrathin sections were double stained with uranyl acetate and lead citrate, and observed using a JEOL 100CXII TEM operated at $60 \mathrm{kV}$.

For SEM study, isolated and purified oocyst suspension was fixed for $4 \mathrm{~h}$ in $2.5 \%$ glutaraldehyde in $0.1 \mathrm{M}$ Na-cacodylate buffer ( $\mathrm{pH} 7.3)$ at $4^{\circ} \mathrm{C}$ and washed for $30 \mathrm{~min}$ in the same buffer. Samples were then dehydrated in an ethanol series, critical point dried in $\mathrm{CO}_{2}$ using a Polaron E3000 and sputter-coated in a Polaron SC 500 using $60 \%$ gold-palladium. They were examined with a JEOL JSM 6700F scanning electron microscope operated at $5 \mathrm{kV}$. 

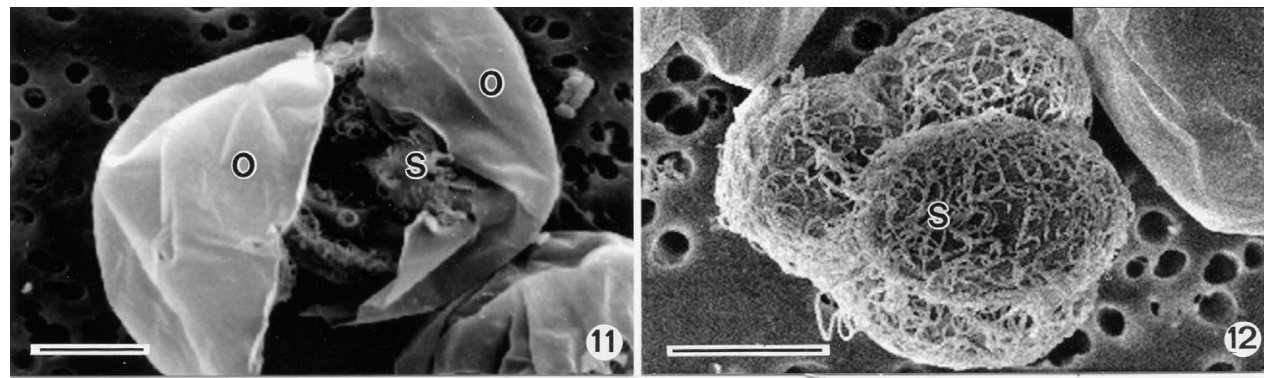

Figs. 11 to 14. Goussia lusca n. sp. infecting Trisopterus luscus. Scanning electron microscopy photographs of sporogonic stages of Goussia lusca. Fig. 11. Oocyst (O) containing sporocysts (S); scale bar $=5 \mu \mathrm{m}$. Fig. 12 . Sporocysts (S) joined in aleatory position and cov-
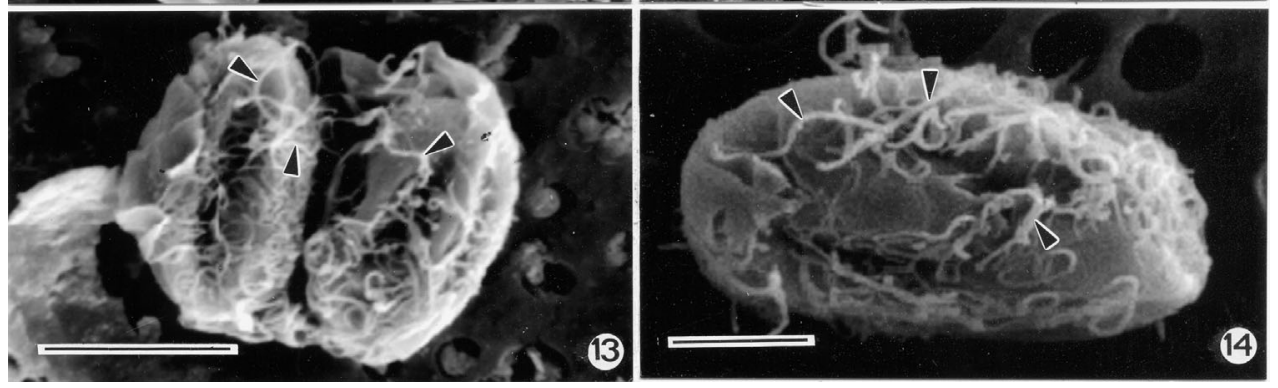
ered by a multi-lamellated outer wall showing external projections; scale bar $=2 \mu \mathrm{m}$. Fig. 13. Arrangement of sporocysts inside the oocysts; scale bar $=5 \mu \mathrm{m}$. Fig. 14. Detail of the sporocyst wall showing the outer multilamellated filamentous extensions (arrowheads); scale bar $=2 \mu \mathrm{m}$

\section{RESULTS}

Description of Goussia lusca n. sp. (Figs. 1 to 15, Table 1)

Using light microscopy, we were able to observe different phases of the coccidian life cycle disseminated in the liver tissues of the pouting Trisopterus luscus. Using interference contrast optics (Nomarski) we observed numerous unsporulated oocysts and sporocysts in parasitized tissue samples of the host's cell) (Figs. 1 to 4). In some cases, walls of several oocysts abutted each other, suggesting that they had been formed by macrophages into groups and later surrounded by a connective tissue capsule (Figs. 1 to 3).

Mature oocysts were $31.69(28.8-35.4) \mu \mathrm{m}(\mathrm{n}=25)$ in diameter. Each oocyst contained 4 ellipsoidal sporo- cysts arranged in an aleatory position and measuring $13.7(13.1-14.4) \times 9.24(8.52-9.84) \mu \mathrm{m}$. Each sporocyst contained 2 sporozoites (Table 1, Figs. 1 to 4 ).

Ultrastructural analysis revealed the presence of different developmental phases of the coccidian disseminated in the liver tissue. Sporoblasts or immature sporocysts were observed limited by a single membrane and containing a prominent nucleus and numerous electron-lucent polysaccharide granules (Fig. 5). Mature sporocysts containing 2 sporozoites or infective cells (Fig. 6) revealed a sporocyst wall consisting of a dense inner layer $115 \mathrm{~nm}$ thick, transversally striated at $15 \mathrm{~nm}$ intervals, regularly intercalated by thin grooves $10 \mathrm{~nm}$ in size with $5 \mathrm{~nm}$ electron-lucent spaces, and separated from the outer layer by a thin, light space. The outer layer was multilamellated and consisted of $6 \mathrm{~nm}$ thick parallel dense bands alternating at $12.5 \mathrm{~nm}$ intervals with $6.5 \mathrm{~nm}$ thick light spaces. These lamellae formed filamentous extensions of the wall delimited by external dense bands of $7.5 \mathrm{~nm}$ thickness (Figs. $7 \& 12$ to 15). The dehiscence suture, a characteristic feature of the genus, was present in the sporocysts (Figs. 6, 7 \& 15).

Unsporulated and sporulated oocysts observed in the liver tissue were often enveloped in a yellowish-brown matrix or 'yellow body' composed of amylopectin granules from the parasite and necrotic or aggregated host liver cells and oocysts (Figs. 2 \& 10). Sometimes it was also
Fig. 15. Schematic drawing of the sporocyst wall (sW) consisting of an inner (iW) and outer wall (oW) 


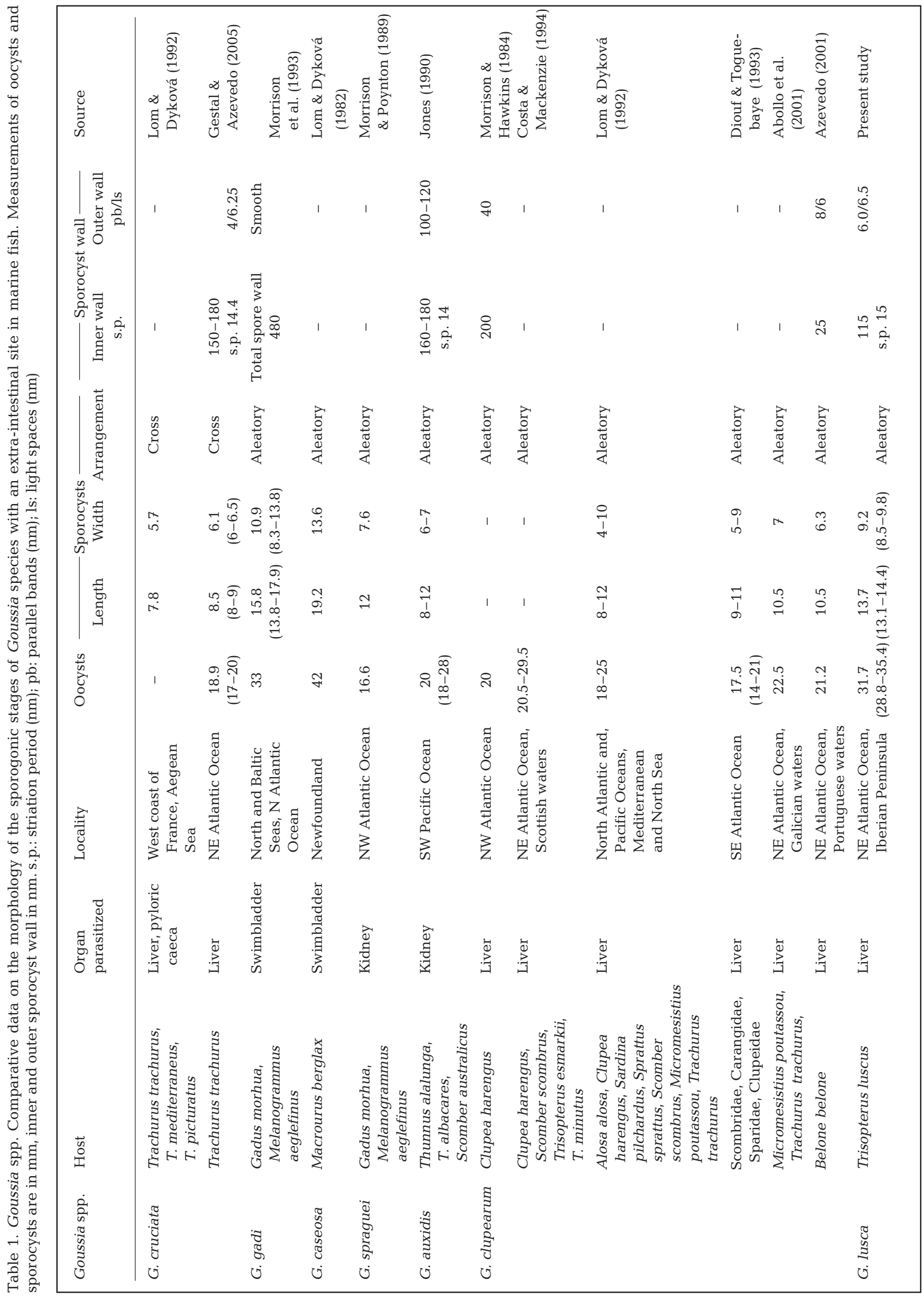


possible to observe sporocysts outside the oocysts in direct contact with the liver cells (Fig. 8). Parasites undergoing degeneration and aggregations of amylopectin granules were frequently observed to be surrounded by host inflammatory cells (Figs. $9 \& 10$ ).

No external clinical signs were seen in any of the fish. However, in severe infections, we observed large agglomeration of oocysts encapsulated by layers of concentrically arranged connective tissue forming large granulomes, replacing the host liver parenchyma (Fig. 1).

\section{Taxonomic description}

Specimens. Syntypes (ultrathin sections of fish liver containing sporogony stages with mature sporocysts) were deposited in the International Protozoan Type collection, Smithsonian National Museum of Natural History, Washington DC (Accession No.: USNM 1089 187).

Locality. NE Atlantic coasts off the Iberian Peninsula, $41^{\circ} \mathrm{N}, 7^{\circ} \mathrm{W}$ ).

Host. Trisopterus luscus (Linnaeus, 1758).

Site of infection. Hepatic parenchyma.

Etymology. The specific epithet refers to the host species Trisopterus luscus.

\section{DISCUSSION}

Classification of the coccidian parasites (Apicomplexa: Eimeriorina) on the generic and family levels is traditionally based on characteristics such as the life cycle, infected organs, morphological structure and size of the sporogonic stages, number and disposition of sporocysts and sporozoites in the exogenous stages and host specificity (Levine, 1982). The genus Goussia was traditionally treated as a synonym of the genus Eimeria because oocysts contained 4 sporocysts, each having 2 sporozoites, even though the excystation system differed from that of the Eimeria species, since it lacked the Stieda body but showed a bivalved sporocyst structure with a sporocyst wall consisting of 2 jointed plates that are opened for the excystation process. Because of these typical characteristics, the genus Goussia Labbé, 1896 was revived by Dyková \& Lom (1981), who placed all fish coccidians with these characteristics in this genus and described G. clupearum as the type species. Our ultrastructural study showed that the coccidian parasite in the liver of pouting described in the present study presented all these taxonomic characteristics, thus allowing us to identify it as belonging to the genus Goussia.

A large number of Goussia species have been described to date. However, among those described from marine teleosts, only a few have been reported from an extra-intestinal location (Table 1), and even fewer described using ultrastructural techniques. All of the latter differ in a number of morphological features from the species described in the present paper. The development of sporoblasts, sporocysts and sporozoites of the our G. luscus are similar to those of G. clupearum described in marine fish, and even to those described in other Trisopterus species, such as T. minutus and T. esmarkii in Scottish waters (Table 1). However, they differ in oocyst and sporocyst size. The results obtained by TEM also showed that they differ from $G$. clupearum at the striation period of the inner layer and the multilamellated outer layer of the sporocyst wall. In addition to the differences in oocyst and sporocyst size and the striation period of the sporocyst wall, the aleatory arrangement of the sporocysts inside the oocysts of G. lusca is also different from the characteristic cross arrangement observed in G. cruciata. The oocyst and sporocyst size and the internal arrangement of the sporocysts observed in G. gadi could be considered similar to those of G. lusca. However, the outer wall of the sporocysts is different, in that it lacks the filamentous extensions that were observed in $G$. gadi. Similarly, this new species differs from G. auxidis, G. spraguei and G. caseosa with respect to the measurements at the various sporogonic stages, and to the host and organ it infects.

The presence of isolated sporocysts in direct contact with host cells has previously been described by Azevedo (2001) in Goussia clupearum parasitizing Belone belone and also by Gestal \& Azevedo (2005) in G. cruciata infecting the horse mackerel Trachurus trachurus. It is not known whether the life cycle of G. clupearum depends on an intermediate host (Morrison \& Hawkins 1984). In fish, direct transmission without an intermediate host has been demonstrated only in piscine coccidians and also recently in intestinal coccidian such as G. carpelli (Lom \& Dyková, 1992). However, direct transmission by auto-reinfection could occurs in extra-intestinal Goussia species, which justify the presence of free sporocysts in the host tissue, which was yet suggested by Azevedo (2001).

The hepatic coccidiosis observed in Trisopterus luscus, with the formation of large agglomerates of oocysts developing granuloms of connective tissue or fibrotic capsules and producing a partial replacement of the host liver parenchyma by the parasite, clearly supports previous reports that infection by Goussia species contributes to a deterioration in host condition due to loss of functional activity of the liver, leading to a reduction in total body weight and thus in the market value of infected fish (MacKenzie 1981, Kent \& Hedrick 1985, Jendrysek et al. 1994, Abollo et al. 2001, Gestal \& Azevedo 2005). Several authors (Morrison \& 
Hawkins 1984, Costa \& Mackenzie 1994, Gestal \& Azevedo 2005) have described the eventual destruction of the functional parenchyma and the development of inflammatory reactions close to degenerate parasites and 'yellow bodies' from fish infected with extra-intestinal Goussia species). This underlines the claim that this group of parasites could be considered as a significant pathogen with important effects on infected fish.

Future research should aim towards a better understanding of the life cycle, host-parasite interactions, and induced pathology and molecular phylogenetic studies using analysis of 18S rRNA sequences are needed to clarify many biological features of this interesting group of fish coccidia.

Acknowledgements. This work was supported by a MarieCurie Fellowship Contract (no. QL K5-CT-2002-51703) (C.G.) under the Fifth Framework Programme of the European Community. We thank Mr. João Carvalheiro for technical assistance with photography.

\section{LITERATURE CITED}

Abollo E, Calvo M, Pascual S (2001) Hepatic coccidiosis of the blue whiting, Micromesistius poutassou (Risso), and horse mackerel, Trachurus trachurus (L.), from Galician waters. J Fish Dis 24:335-343

Anderson RM, Gordon DM (1982) Processes influencing the distribution of parasite numbers within populations with special emphasis on parasite induced host-mortalities. Parasitology 85:373-398

Azevedo C (2001) Fine structure of sporogonic stages of Goussia clupearum (Apicomplexa: Eimeriidae) in the liver of infected fish (Belone belone L.), using light and electron microscopy. Parasitol Res 87:326-330

Costa G, MacKenzie K (1994). Histopathology of Goussia clupearum (Protozoa: Apicomplexa: Coccidia) in some marine fish from Scottish waters. Dis Aquat Org 18: 195-202

Diouf JN, Toguebaye BS (1993) Studies of coccidian parasites of fish from the coast of Senegal (West Africa): new species pf the genus Goussia (Apicomplexa, Eucoccidiida, Calyptosporidae). Zool Scr 22:117-126

Dyková I, Lom J (1981) Fish Coccidia. Critical notes on life

Editorial responsibility: Wolfgang Körting,

Hannover, Germany cycles, classification and pathogenicity. J Fish Dis 4: 487-505

Dyková I, Lom J (1983) Fish Coccidia: an annotated list of described species. Folia Parasitol 30:193-208

Fournie JW. Overstreet RM (1993) Host specificity of Calyptospora funduli (Apicomplexa: Calyptosporidae) in atheriniform fishes. J Parasitol 79:720-727

Gestal C, Azevedo C (2005) Ultrastructure of Goussia cruciata (Apicomplexa: Coccidia) infecting the liver of horse mackerel, Trachurus trachurus (L.), from Ibero-Atlantic waters. J Fish Dis 28:125-132

Gestal C, Abollo E, Pascual S (1999) Evaluation of a method for isolation and purification of sporocysts of the cephalopod coccidian parasite Aggregata Frenzel, 1885 (Apicomplexa: Aggregatidae). Iberus 17:1115-121

Jendrysek S, Steinhagen D, Drommer W, Körting W (1994) Carp coccidiosis: intestinal histo and cytopathology under Goussia carpelli infection. Dis Aquat Org 20:171-182

Jones JB (1990) Goussia auxidis (Dogiel, 1948) (Apicomplexa: Calyptosporidae) from tuna (Piscis: Scombridae) in the South Pacific. J Fish Dis 13:215-223

Kent ML, Hedrick RP (1985) The biology and associated pathology of Goussia carpelli (Léger and Stankovitch) in goldfish Carassius auratus (Linnaeus). Fish Pathol 20: 485-494

Levine ND (1982) Taxonomy and life cycles of Coccidia. In: Long PL (ed) The biology of the Coccidia. University Park Press, Baltimore, MD, p 1-34

Lom J, Dyková I (1982) Some marine fish coccidian of the genera Eimeria Schneider, Epieimeria Dyková \& Lom and Goussia Labbé. J Fish Dis 5:309-321

Lom J, Dyková I (1992) Protozoan parasites of fishes. Elsevier Science, Amsterdam

MacKenzie K (1981) The effect of Eimeria sp. infection on condition of the blue whiting, Micromesistius poutassou. J Fish Dis 4:473-486

Molnar K, Ostoros G, Baska F (2005) Cross-infection experiments confirming the host specificity of Goussia spp. (Eimeriidae: Apicomplexa) parasitizing cyprinid fish. Acta Protozool 44:43-49

Morrison CM, Hawkins WE (1984) Coccidians in the liver and testis of the herring Clupea harengus L. Can J Zool 62: 480-493

Morrison CM, Poynton SL (1989) A new species of Goussia (Apicomplexa, Coccidia) in the kidney tubules of the cod, Gadus morhua L. J Fish Dis 12:533-560

Morrison CM, Leger JP, Morrison CA (1993) Light microscopy and ultrastructural study of sporilation of Goussia gadi (Apicomplexa: Coccidia) in the swimbladder wall of haddock Melanogrammus aeglefinus. Dis Aquat Org 17:181-189

Submitted: May 9, 2005; Accepted: January 30, 2006

Proofs received from author(s): July 3, 2006 